\title{
New Growth Approach to Poverty Alleviation
}

\section{Citation}

Aghion, Philippe, and Beatriz Armendáriz de Aghion. "A new growth approach to poverty alleviation." Understanding poverty (2004): 73-84. Cambridge, UK: Cambridge University Press.

\section{Published Version}

doi:10.1093/0195305191.003.0005

\section{Permanent link}

http://nrs.harvard.edu/urn-3:HUL.InstRepos:34330190

\section{Terms of Use}

This article was downloaded from Harvard University's DASH repository, and is made available under the terms and conditions applicable to Other Posted Material, as set forth at http:// nrs.harvard.edu/urn-3:HUL.InstRepos:dash.current.terms-of-use\#LAA

\section{Share Your Story}

The Harvard community has made this article openly available.

Please share how this access benefits you. Submit a story.

Accessibility 


\title{
A New Growth Approach to Poverty Alleviation
}

\author{
Philippe Aghion and Beatriz Armendáriz de Aghion*
}

September 18, 2004

\section{Introduction}

Growth theory has often been perceived by development economists as being orthogonal to their main concern, namely, that of understanding the sources of persistent poverty and stagnation in households and villages, and of designing policies aimed at overcoming them. Growth theory, they would argue, is a subdiscipline of macroeconomics: it features economies with representative producers and consumers; and it focuses on aggregate savings and the role of physical or human capital accumulation in long-run growth and convergence. In particular, growth theory is not so concerned with poverty and inequality between rich and poor individuals within a country.

Empirical growth studies have been equally perceived as being too aggregate: most often carried out at a cross-country level, they involve aggregate variables such as average per capita gross domestic product (GDP), average total factor productivity (TFP), average savings rate, average measures of financial development, or average education indicators. In contrast, by focusing directly on households and local institutions and infrastructure, and by using highly targeted control experiments to evaluate the effectiveness of such institutions in a particular community or village, development economists feel entitled to believe that they have found the right approach to deal with the issue of poverty alleviation, and of how to close the gap between rich and poor.

This paper is an attempt to break the divide between growth and development economics. Using the example of India over the past decades, we argue that innovation and/or productivity growth have been main engines of poverty reduction in that country. We also argue that new growth theories can shed light on this process. Moreover, these can also explain why growth and poverty reduction has not occurred in Latin America. The reminder of this essay is organized as follows. In Section 2 we summarize what is currently known about the recent evolution of growth and poverty indicators in India over the past four decades. In Section 3, we provide a very brief presentation of new growth theory and of some of its main predictions. In Section 4 we use our description of new growth theory to analyze the reform process in India. In Section 5, we show

*Harvard University 
that the 1991 reforms have had unequalizing effects on productivity and profitability across industries and states. Finally, in Section 6 we reflect upon the contrasting experience of Asia and Latin America with regard to productivity growth and poverty alleviation.

\section{Some recent findings on growth, poverty and inequality in India}

It is a well established fact that poverty started a pronounced and steady decline in India as of the 1960s and 1970s (see Datt and Ravallion (1998)). But meanwhile there was little growth in the manufacturing sector. So what explains this reduction in poverty? Here, the now well-established answer is that it is the green revolution and the resulting boost to productivity in agriculture, that made it happen ${ }^{1}$. That is, the diffusion of a new fundamental innovation to the entire agricultural sector, and its spillovers onto the urban sector -via its effects on food prices and wages ${ }^{2}$. Somewhat surprisingly, this declining poverty trend has been sustained over the past two decades, even though the productivity impact of the green revolution had been largely exhausted. In their recent paper on "Poverty and Inequality in India", Angus Deaton and Jean Drèze (2002) analyze the recent evolutions of inequality and poverty in India over the past decades. They use survey data provided by three quinquennial rounds of questionnaires (respectively conducted over time intervals 1987-1988, 19931994, and 1999-2000) on households' consumption of a given set of durable and

non-durable goods. This information in turn is used to evaluate the number of individuals that lie below the poverty line divided by the total population, or the so-called "head-count ratio".

The first main finding reported by Deaton and Drèze (see Table 1 below) is that, even after one adjusts for changes in the design of questionnaires from one round to the next (official methodology), or for changes in price indexes over time (adjusted methodology), poverty -both in rural and urban areas, has substantially declined over the past twenty years.

\section{$T A B L E 1$ : Poverty Reduction in India Headcount Ratios (100\%)}

\footnotetext{
${ }^{1}$ As well explained in Todaro and Smith (2003), "after the green revolution of the late 1960 s and early 1970s, agricultural production started increasing at an annual rate of $3 \%$. This was largely due to improvements in agricultural technologies and irrigation systems. As a result, India became self-sufficient in grain production. It was able to increase its wheat production from 10 million tons in 1964 to over 45 million tons in 1985."

${ }^{2}$ See Eswaran and Kotwal (1994). We thank Dilip Mookherjee for pointing this reference to us.
} 


\begin{tabular}{ccccccc} 
& \multicolumn{3}{c}{$\begin{array}{c}\text { Official } \\
\text { Methodology }^{a}\end{array}$} & \multicolumn{3}{c}{ Adjusted $^{\text {Estimates }^{b}}$} \\
Rural & $1987-88$ & $1993-94$ & $1999-00$ & $1987-88$ & $1993-94$ & $1999-00$ \\
Urban & 39.4 & 37.1 & 26.8 & 39.0 & 33.0 & 26.3 \\
39.1 & 32.9 & 24.1 & 22.5 & 17.8 & 12.0
\end{tabular}

a. Consumption data from the Planning Commission National Sample Survey b. Consumption data adjusted for improved comparability, and price indexes

Source: Deaton, Angus, and Drèze (2002)

Deaton and Drèze also find the same pattern when using poverty gap or agricultural wage measures instead of the headcount. A second finding is that consumption inequality across individual households, has increased between the period 1993-1994 and the period 1999-2000, which in turn is consistent with Abhijit Banerjee and Thomas Piketty's (2001) finding of a substantial increase in income inequality among the highest income earners. Moreover, such findings are consistent with the result encountered in the 2004 article by Philippe Aghion, Robin Burgess, Stephen Redding, and Fabrizio Zilibotti ( (ABRZ) that the variance of profits across registered manufacturing firms in India, has increased dramatically since 1991 .

Now, what has happened to growth over the same period? Here, the most informative study is by Dani Rodrik and Arvind Subramanian (2004), who find (see Table 2 below) that after a prolonged stagnation, all productivity variables, namely real per capita GDP, real GDP per worker, and TFP, have taken off since the early 1980s and kept growing at a sustained high rate ever since.

\begin{tabular}{lcccc}
\multicolumn{4}{c}{ TABLE } & 2 : Average Growth Rates in India* \\
& & & & \\
& $1960-70$ & $1970-80$ & $1980-1990$ & $1990-99$ \\
IMF Estimates & & & & \\
Output & 3.75 & 3.16 & 5.64 & 5.61 \\
Output per worker & 1.77 & 0.86 & 3.69 & 3.30 \\
Total Factor Productivity & 1.17 & 0.47 & 2.89 & 2.44
\end{tabular}

*Source: Table 1 in Rodrik - Subramanian (2004)

Thus, a very first look at the past four decades suggests that the green revolution first, and then the advent of sustained productivity growth in the manufacturing sector, explain this poverty alleviation phenomenon to a large extent. In both instances, technology and entrepreneurship in the rural and then in the urban sectors, have played a key role. This brings us to the next section. 


\section{New growth theory in a nutshell}

Three main ideas underlie the new theories of endogenous technical progress ${ }^{3}$. First, productivity growth is primarily driven by the rate of technological innovations, in the form of new products, new processes, and new ways of organizing production. Second, most innovations are the result of entrepreneurial activities or investments, e.g R\&D investments, which involve risky experimentation and learning. Third, the incentive to engage in innovative investments is itself affected by the economic environment.

Here are five prime examples of institutions and/or policies that affect longrun productivity growth through their impact on entrepreneurs' incentives, or through their ability to make innovative investments:

1. An effective education system will have a positive effect on long-run productivity growth, both by increasing the efficiency of innovation technologies and investments (both are highly skill intensive) and also by reducing the cost of skill labor which in turn increases the profits that accrue to successful innovators. As shown by Benhabib and Spiegel (1994) or Krueger and Lindhal (2001), a higher stock of human capital increases countries' ability both to innovate at the frontier and also to imitate more advanced technologies. ${ }^{4}$

2. A legal environment that allows entrepreneurs to appropriate a significant fraction of the revenues generated by their innovative investments. In particular, better protection of (intellectual) property rights or a labor market which is not too unfavorable to employers, will enhance the expected profits from innovation and thereby encourage innovative investments and productivity growth. That better property right protection is growth enhancing, has been widely established by economic history of the past two centuries, and it comes out very clearly from the recent work on the economics of institutions (e.g see La Porta et al (1998), Hall and Jones (1999), and Acemoglu et al (2001)). The role of labor market regulations is equally important as we show in Aghion, Burgess, Redding and Zilibotti (2004) and report in Section 4 below.

3. Macroeconomic stability also tends to foster long-term productivity growth ${ }^{5}$; it reduces interest rates and therefore increases the present discounted value of rents to a successful innovator and, more generally, it encourages entrepreneurs to be more forward-looking and emphasize R\&D as well as other types of long-term innovative investments over time. As recently

\footnotetext{
${ }^{3}$ See Romer (1990) and Aghion-Howitt (1992, 1998).

${ }^{4}$ Vandenbussche, Aghion, and Meghir (2004) use similar cross-country panel data to show that the closer a country initially lies with respect to the technological frontier, the higher the relative importance of higher education relative to primary/secondary education for productivity growth.

${ }^{5}$ Cross-country evidence of a negative correlation between volatility and growth, was first provided by Ramey and Ramey (1995). See also Aghion, Angeletos, Banerjee and Manova (2004).
} 
shown by Aghion, Angeletos, Banerjee, and Manova (2004), the latter is particularly true in countries with lower levels of financial development.

4. As shown by Levine et al ${ }^{6}$, financial development is of paramount importance for long-run productivity growth, as it makes it easier for entrepreneurs to finance their innovative investments. More recently, Aghion, Howitt and Mayer (2004) show that financial development is a key variable explaining why some countries converge towards the technological frontier whereas other countries diverge. The same considerations can explain why, within a given country, some firms or sectors grow faster than others. They can also explain why productivity growth may increase inequality. This in turn follows from the following considerations: (i) in an environment with credit constraints, firms cannot borrow more than a multiple of their current profits; (ii) the current equilibrium profits of a firm are typically proportional to its current productivity; (iii) the $\mathrm{R} \& \mathrm{D}$ cost of catching up with the technological frontier, is typically proportional to the frontier productivity level. Thus, the lower the current productivity of a firm, the more costly it is for that firm to catch up with the technological frontier, and therefore the lower the probability of technological catch-up. Hence, in an economy with low financial development, firms that are initially closer to the technological frontier will tend to grow faster than firms initially further below the frontier.

5. Higher competition among incumbent firms and/or a higher entry threat (e.g as induced by trade liberalization or a reduction in entry or licensing costs), will tend to encourage innovations by incumbent firms aimed precisely at escaping competition or entry by potential rivals. The incentive to react to higher entry threat or higher competition by increasing innovative investments, will tend to be higher for firms technologically close to their competitors in the same industry or to potential entrants at the technological frontier. Those are indeed the most likely to escape competition or entry through innovating. On the other hand, higher competition or entry will have either no effect or a negative effect on backward firms which stand little chance of competing in the post-liberalization environment. ${ }^{7}$

Our view is that the new growth approach outlined in this section provides good lenses whereby to interpret the recent poverty reduction in India. While the relation between the new growth approach and the Green Revolution is well established $^{8}$, in the next section we shall argue that this approach is equally relevant to understand what happened to growth and poverty over the past two decades.

\footnotetext{
${ }^{6}$ In particular, see King and Levine (1993) and Levine et al (2002).

${ }^{7}$ See Aghion, Bloom, Blundell, Griffith and Howitt (2004), Aghion, Burgess, Redding and Zilibotti (2004) and Aghion, Blundell, Griffith, Howitt, and Prantl (2004).

${ }^{8}$ See the 1998 World Development Report. which offers a detailed description of the Green Revolution and of how its diffusion was facilitated by suitable government policy on education, intellectual property, FDI, technological licensing, and by "vast programs to help focus public (research) laboratories on the needs of productive sector".
} 


\section{Two waves of growth-enhancing reforms in In- dia}

There is a debate on what triggered the Indian growth takeoff. On the one hand, ABRZ emphasize the importance of the 1991 reforms. They argue that up this point, firms and industries were constrained both, internally by pervasive central government control through public ownership and a tight control over licensing, and externally by high tariff and non-tariff barriers and controls on foreign direct investment. As a response to the balance of trade crisis, a New Industrial Policy was introduced in 1991, pretty much in line with what the new growth theories outlined in the previous section might suggest, namely: (i) trade liberalization, with a $51 \%$ reduction in tariffs over $97 \%$ of products, which increased competition and entry; (ii) a boost to foreign direct investment, with the automatic approval of foreign technology agreements involving up to $51 \%$ of foreign equity participations in a large number of industries; this would both, foster entry and also allow the Indian enterprise sector to partly circumvent financial constraints; (iii) deregulation, with a substantial easing on procedures to start up a new production unit or manufacture new products, and privatization, with a dramatic reduction in the number of sectors reserved for public sector, would further encourage innovation by incumbent firms and also stimulate entry; (iv) further expansion on allowed production capacities and reductions in corporate income tax, which increased entrepreneurs' ability to appropriate the reward from their innovative investments.

However, Rodrik and Subramanian (2002) showed that the Indian take-off predates the 1991 reforms and dates back to the early 1980s. But then, can we really attribute the high growth rates of the past decade to the liberalization reforms of 1991? Or did growth over the whole period result instead from other changes that occurred in 1980 or before and would have much less to do with what new growth theories suggest?

In fact Rodrik and Subramanian (2002) identify two phases in the Indian growth experience of the last two decades: there is first what they call the phase of "pro-business" reforms, starting in 1980 with the return of Indira Gandhi and the subsequent rise of Rajiv Gandhi. What the two leaders did was to send a clear signal to the enterprise sector that the Congress Party and the Indian government would abandon its previous pro-socialism and pro-poor rhetoric and favor the expansion of existing private companies through pro-business measures such as the ease of restriction on capacity expansion, the removal of price controls, and the reduction of corporate taxes. While this reform package did not emphasize trade or entry liberalization, yet if we believe the new growth approach outlined above, all these measures should be expected to foster productivity growth by increasing incumbent entrepreneurs' ability to appropriate the rents from their innovative investments. And indeed, this policy shift by the Indian government was to be followed by a growth acceleration which in turn was primarily due to a continuous increase in productivity, and to a lesser extent to factor accumulation. That the sequencing between the policy change and 
the growth takeoff was not spurious but rather reflected a causal relationship, is shown by Rodrik and Subramanian in two ways: first, they show that the growth upsurge has been more pronounced in Indian states where members of the local government belonged (or were allied with) the ruling Congress Party; second, there was a significant shift in private investment from the household to the manufacturing sector, which in turn reflects a positive reaction of the private sector to what they perceive as an improved investment climate.

As explained above, it is not until 1991 that markets and trade were truly liberalized, and here starts the second phase of the Indian growth experience. As argued in the previous section, higher competition and entry should be expected to further encourage innovative investments aimed as escaping them, which in turn would explain why growth continued at the same rate during the 1990s in spite of the balance of trade crisis. However, unlike in the 1980s, in the 1990s poverty reduction appears to have slowed down and poverty levels even fluctuated in the early 1990s. As we shall argue in the next section, such fluctuations might be explained by the fact that trade liberalizations entails winners and losers, both within and across sectors.

\section{The unequalizing effects of the Indian liberal- ization experience}

ABRZ (2004) analyze the impact of liberalization on the performance of registered manufacturing firms. ${ }^{9}$ They run panel regressions of performance measures such as TFP growth or profitability in a particular industry in a particular state at a particular time. They regress these performance measures over: (i) the pre-reform proximity of the state-industry to the Indian technological frontier (defined as labor productivity in the 3-digit state-industry in 1990 divided by labor productivity in the most productive 3-digit state-industry in that year); (ii) a dummy variable that captures the liberalization reform: this variable is equal to zero before 1991 and to one thereafter., (iii) labor market institutions at the state level, and in particular the extent to which labor regulations in the state are more "pro-employer" or more "pro-employee" relative to other states. To capture state-level institutions, ABRZ follow Besley and Burgess (2003) which uses the number and direction (pro-employer or pro-employee) of the state-level amendments to the central 1947 Industrial Disputes Act to measure the extent to which the labor regulations are more pro-employer or more pro-employees in the different states of India. They look at both, whether the direction of regulatory change over the 1980-1997 period affected industry performance and whether pre-reform labor market institutions affected post-reform performance. ABRZ also control for state-industry and year fixed effects, and the standard errors are adjusted for clustering by state to deal with problems of serial correlation.

\footnotetext{
${ }^{9}$ These correspond to firms with more than 10 employees. Over the period 1980-1997, these firms account for $10 \%$ of GDP, i.e twice as much as the unregistered sector.
} 
The key empirical results from ABRZ can be summarized as follows: TFP, investment and profitability respond more positively to the liberalization reform in industries that are initially closer to the technological frontier. Moreover, technological progress and the growth in profitability are slower in industries located in more pro-employee states; this is fully consistent with the view put forward by new growth theories, that the institutional environment in which firms operate, affect their investments incentives and subsequently their productivity growth performance. Finally, liberalization increases the negative impact of pro-worker regulations on productivity growth. Thus, greater rent extraction by workers reduces firms' incentives to fight entry through more intense innovative investments. That investments reacted in the same heterogenous way as profitability and productivity across firms in different states or at different distances from their industry frontier, is direct evidence that what happened during the 1990 s, amounted to more than a pure selection between firms that were intrinsically more performing and therefore could better withstand the liberalization shock and the less performing firms that such reforms would condemn to obsolescence. Rather, as predicted by the new growth theories, it is through their effects on firms' investment incentives in different states and industries that the liberalization reforms affected subsequent productivity growth. And it is because firms' incentives to innovate and respond to the increased entry threat differed across states and across initial levels of technological development, that we observed a heterogeneous growth response to these reforms.

Thus, the liberalization reforms of 1991 increased average productivity and profitability over the subsequent decade, but it also increased inequality. And while poverty reduction slowed down, it occurred nevertheless on average over the whole period.

\section{Why did poverty reduction occur in Asia and not in Latin America?}

In our discussion so far we tried to argue that poverty alleviation and economic development should also be addressed from a macro-growth perspective, not just from a pure micro-household viewpoint. However, someone critical of our way of thinking, would bring out the example of Latin American countries where poverty indicators have deteriorated over the past decades even though (or may be because of) these countries implemented a "Washington consensus" type of package (price and trade liberalization, privatization, and stabilization). Interestingly, neither poverty nor growth indicators have improved in those countries

during the recent period, so that Latin America is not a counter-example to begin with. Yet, it is worth understanding why Latin American countries are not growing. Part of a possible answer to this question relies on the combination of three elements: inequality, education, and trade. First, inequality, 
which is higher in Latin America than in Asia ${ }^{10}$. As suggested by Alesina and Rodrik (1994) or Benabou (1996), too much inequality tends to be detrimental to growth especially in less developed countries. Second, education, which is far more widespread in East Asian countries like Korea or Hong Kong than in Latin America. Third, trade: East Asian countries and more recently China, have followed more aggressive export promotion strategies combined with high investments of physical and human capital. Another part of the answer to the above question, may thus lie in differences in growth strategies pursued by different countries and regions: on the one hand, through their export promotion policies Asian countries have targeted their efforts on imitating the most innovative sectors in developed countries, whereas Latin American countries followed import substitution policies driven by the local market and by a static view of comparative advantage.

The reasons why these growth-enhancing factors are missing in some parts of the world and not in others, has been the subject of a fast-growing literature on the economics of institutions (see La Porta et al (1997), Hall and Jones (2000) and Acemoglu et al (2001)). But this literature has not yet delivered recommendations on new mechanisms that might potentially help overcome legal and political obstacles to the implementation of more effective pro-education, pro-health, pro-private-sector growth, policies. But here is precisely where, we believe, the growth and household approaches can be reconciled into a renewed theory of development. More specifically, to maximize the effectiveness of topdown growth-enhancing government programs, we see a role for nongovernmental organizations (NGOs) to monitor the implementation of these programs. For example, microfinance institutions, most of which are NGOs, have vested interests in envigilating household participation in health and education programs while monitoring the quality of these programs, in addition to obviously helping to promote financial development and the banking sector. However, in the absence of top-down strategies, all what these microfinance institutions have achieved is to help people survive within poverty, and not to grow out of it, as shown by recent empirical evidence (see Armendariz and Morduch (2004)).

\footnotetext{
${ }^{10}$ In its 1998 World Development Report, the World Bank estimated that the average Gini coefficients for Latin America and East Asia, were respectively equal to 0.49 and 0.40, which indeed reflects a higher level of inequality in Latin America compared to East Asia.
} 


\section{References}

[1] Acemoglu, Daron, Philippe Aghion, and Fabrizio Zilibotti, 2002. "Distance to Frontier, Selection, and Economic Growth", NBER Working Paper 9066

[2] Acemoglu, Daron, Simon Johnson, and James Robinson, 2001. "The Colonial Origins of Comparative Development: An Empirical Investigation", American Economic Review, 91, 1369-1401

[3] Aghion, Philippe, Marios Angeletos, Abhijit Banerjee, and Kalina Manova, 2004, "Volatility, R\&D, and Growth", mimeo, Harvard University

[4] Aghion, Philippe, Nicholas Bloom, Rachel Griffith, and Peter Howitt, 2004. "Competition and Innovation; An Inverted-U relationship", mimeo, Harvard University

[5] Aghion, Philippe, Richard Blundell, Rachel Griffith, Peter Howitt, and Susan Prantl, 2004." Entry, Innovation and Growth: Theory and Evidence", mimeo, Harvard University

[6] Aghion, Philippe, Robin Burgess, Stephen Redding, and Fabrizio. Zilibotti, 2003." The Unequalizing Effect of Liberalization: Theory and Evidence from India", mimeo Harvard University and University College London.

[7] Aghion, Philippe, and Peter Howitt, 1992. "A Model of Growth through Creative Destruction", 60, 323-351

[8] Aghion, Philippe, Peter Howitt, and David Mayer, 2003. "The Effect of Financial Development on Convergence: Theory and Evidence", NBER Working Paper 10358

[9] Aghion, Philippe and Peter Howitt,1998. Endogenous Growth Theory, MIT Press

[10] Alesina, Alberto, and Dani Rodrik, 1994. "Distributive Politics and Economic Growth", Quarterly Journal of Economics, 108, 465-490.

[11] Armendáriz de Aghion, Beatriz, and Jonathan Morduch, 2004. The Economics of Microfinance, MIT Press, forthcoming

[12] Banerjee, Abhijit, and Andrew Newman, 1993. Occupational Choice and the Process of Development", Journal of Political Economy, 101, 274-298.

[13] Benabou, Roland, 1996. "Inequality and Growth", NBER Macroeconomics Annual, 11, MIT Press

[14] Benhabib, Jess, and Mark Spiegel, 1994. "The Role of Human Capital in Economic Development: Evidence from Aggregate Cross-country Data", Journal of Monetary Economics, 34, 143-173. 
[15] Datt, Gaurav, and Martin Ravallion, 1998. "Farm Productivity and Rural Poverty in India", Food Consumption and Nutrition Division Paper No 42, International Food Policy Research Institute.

[16] Deaton, Angus, and Jean Drèze, 2002. "Poverty and Inequality in India: A Reexamination", Working Paper 107, Princeton University.

[17] Eswaran, Mukesh, and Ashok Kotwal, 1994. Why Poverty Persists in India?, Dehli, Oxford University Press.

[18] Galor, Oded, and Joseph Zeira, 1993. "Income Distribution and Macroeconomics", Review of Economic Studies, 60, 35-52.

[19] Hall, Robert, and Charles Jones,1999. "Why Do Some Countries Produce so Much More Output per Worker than Others?", Quaterly Journal of Economics, 114, 83-116

[20] King, Robert, and Ross Levine, 1993. "Finance, Entrepreneurship, and Growth", Journal of Monetary Economics, 32, 513-542

[21] Krueger, Alan, and Mikael Lindahl, 2001. " Education for Growth: Why and For Whom?", Journal of Economic Literature, 34, 1101-1136.

[22] Levine, Ross, Norman Loayza, and Thorsten Beck, 2000, "Financial Intermediation and Growth:Causality and Causes", Journal of Monetary Economics, 22, 3-42.

[23] Romer, Paul, 1990. "Endogenous Technical Change", Journal of Political Economy, 98, 71-102.

[24] Rodrik, Dani, and, Arvind Subramanian, 2004. "From "Hindhu Growth" to Productivity Surge: The Mystery of the Indian Growth Transition", mimeo, Harvard University.

[25] Todaro, Michael, and Stephen Smith, 2003. Economic Development, Essex, Pearson Education Limited.

[26] Vandenbussche, Jérome, Philippe Aghion, and Costas Meghir, 2004. "Distance to Frontier and Composition of Human Capital", mimeo HarvardUCL.

[27] World Development Report, 1998. Washington D.C: World Bank. 